\title{
Plastic colored paddings and its effect on the foliar micromorphology of husk tomato (Physalis ixocarpa Brot.)
}

\author{
Marín-Cortez, María del P.; ${ }^{1}$ Rodríguez-Luna, Daniela ${ }^{1}$; Flores-Naveda, Antonio² ${ }^{2}$ Álvarez-Vázquez, Perpetuo ${ }^{3}$ \\ García-López, Josué I. ${ }^{2}$; Camposeco-Montejo, Neymar ${ }^{2 *}$ \\ ${ }^{1}$ Universidad Autónoma Agraria Antonio Narro. Departamento de Horticultura. Saltillo, Coahuila, \\ México. ${ }^{2}$ Universidad Autónoma Agraria Antonio Narro. Departamento de Fitomejoramiento. \\ ${ }^{3}$ Universidad Autónoma Agraria Antonio Narro. Departamento de Recursos Naturales Renovables. \\ *Corresponding author: neym_33k@hotmail.com
}

\begin{abstract}
Objective: To assess the effect of colored plastic paddings on the foliar micromorphology of husk tomato (Physalis ixocarpa Brot.).

Design/methodology/approach: A completely randomized statistical model was used with five treatments (black, white, blue, red and green paddings) with three repetitions each, 95\% reliability and Tukey's mean test ( $\mathrm{P} \leq 0.05)$. To quantify the normalized difference vegetation index (NDVI) a portable GreenSeeker ${ }^{\circledR}$ sensor was used. To measurement of total soluble solids a Atago ${ }^{\circledR}$ Digital refractometer, the density and stomatal index, length and width of stomata were determined with a Carl Zeiss microscope with an integrated camera and the AxionVisionRel measurement software 4.8.

Results: The results show no significant differences in the NDVI and total soluble solids. The micromorphological variables of adaxial stomatal density and adaxial stomatal index were superior in the blue paddings and exceeded black paddings in $95 \%$ and $50 \%$ respectively. The rest of the micromorphological variables were statistically similar, the yield per plant was statistically similar in the black, white, red and green, while blue paddings yield less.
\end{abstract}

Study limitations/implications: blue paddings improve micromorphological characteristics, but not the yield of husk tomato crops.

Findings/conclusions: Some of the foliar micromorphological characteristics of the husk tomato crop are modified by colored plastic paddings; however, the improvement in these variables does not necessarily improve the crop yield, probably due to the absorbed and reflected radiation by the colored plastic paddings.

Keywords: Physalis sp., stomatic density, stomatic index, epidermal cells.

\section{INTRODUCTION}

HUSK tOmato (Physalis ixocarpa Brot.) is a vegetable of great economic importance in MUK COM Mexico. Between 2012 and 2019, Mexican exports of it increased by nine thousand tons on average per year, the United States the main export destination. In 2018, 42,464 hectares were planted and a production of 830 thousand tons was obtained, with a value of 4,352 million pesos. The states that

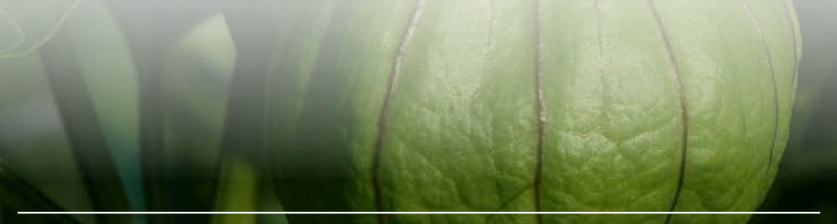

Agroproductividad: Vol. 14, Núm. 4, abril. 2021. pp: 135-142. Recibido: octubre, 2020. Aceptado: febrero, 2021. 
lead the production are Sinaloa, Jalisco, Zacatecas, Michoacán and Puebla (SIAP, 2019). Its importance also lies in its nutritional value, given that it represents a concentrated source of bioactive elements and micronutrients (Vargas et al., 2015). However, like any crop, the species faces problems, which have to be addressed with technical or technological innovation that enhances its production. One of these long-time used innovations is plastic. The most used paddings are black and white, which allows water-saving and increased yields (Canul et al., 2017), decreases weeds incidence in the crops and increases soil temperature (Quintero, 2015; Ruiz et al., 2014). However, paddings are also manufactured in white, silver and to a lesser extent blue, green, red and brown. The above, seek and provide plants with adequate radiation and temperature to enhance their maximum development and productivity (Oliva, 2015), since plants are photosynthetic organisms and depend on solar radiation quality to obtain energy and transform it into carbohydrates (Ganesh et al., 2013).

Radiation is the main factor regulating the different growth stages, development and the vital physiological process throughout a plant's life cycle. In response to radiation, plants developed different structures (photoreceptors) for their perception, through which they can assess the radiation quality (wavelength), intensity, duration and direction (Heijde and UIm, 2012). Studies related to the quality of radiation under photo-selective meshes indicate that the red mesh transmits more total solar radiation, photosynthetic, red, far-red and infrared than the black mesh, while the aluminated mesh transmits more ultraviolet-A light, therefore the blue mesh consequently more blue light and photosynthetically active radiation. In general, under these colored covers, the relative humidity and temperature of the upper leaves increase by $0.2-0.9^{\circ} \mathrm{C}$ as well as their photosynthetic properties: transpiration, stomatal conductance and $\mathrm{CO}_{2}$ assimilation (Ayala et al., 2013). Other studies indicate that photoselective plastics improve the environment and therefore the physiological processes in plants, which translates into higher productivity compared to traditionally marketed plastics (Ramos et al., 2017; Alsadon et al., 2016). Hogewoning et al. (2010) point out that for photosynthesis to adequately happen, without any alterations, it needs a minimum of $7 \%$ blue light and, on the contrary, when there is only red light, the photosynthetic process diminishes and affects growth and development. Therefore, there must be a combination of both for photosynthetic processes to be carried out efficiently. Similar negative effects occur if wavelengths of less than 300 and greater than 900 $\mathrm{nm}$ and climatic-environmental factors are equally involved (Casierra et al., 2011).

To express their maximum phenotypic potential, crops need optimal radiation ranges, which vary depending on the species. To address these particular radiation demands and achieve better use by crops, different plastic color covers and paddings are offered throughout the horticultural market, the above is reflected in increased yield and improvements in the morphological characters of the plant and fruit quality, as previously mentioned. However, the effect of those films and their coloration on the micromorphological component of the plants is not studied. Therefore, in this work, the effect of the coloration of plastic pads on the foliar micromorphology and some performance components of a husk tomato crop was assessed.

\section{MATERIALS AND METHODS \\ Experimental site location}

The experiment was established in a experimental field at the Horticulture Department, Universidad Autónoma Agraria Antonio Narro (UAAAN), Saltillo, Coahuila, Mexico; located at $25^{\circ} 21^{\prime} 24^{\prime \prime} \mathrm{N}$ and $101^{\circ} 02^{\prime} 05^{\prime \prime} \mathrm{W}$, an altitude of $1,762 \mathrm{~m}$ above sea level, mean annual rainfall of $400 \mathrm{~mm}$, mean annual temperature between 12 and $18{ }^{\circ} \mathrm{C}$, and a $\mathrm{BS} 0 \mathrm{k}\left(\mathrm{x}^{\prime}\right)$ dry temperate climate. The used vegetable material was of the "Siquerios F1" variety husk tomato from the Harris Moran seed house.

\section{Seedlings production}

For the seedlings production, 200-cavity polystyrene trays were filled with peat and perlite substrate in a $70: 30 \%$ proportion, previously moistened to field capacity. One seed per cavity was sown at an approximate $0.5 \mathrm{~cm}$ depth and covered with a thin layer of the same mixture substrate, later it was covered with black plastic and kept in a greenhouse to induce germination. After 72 hours the plastic cover was removed and left in the greenhouse for the emergence and the seedlings growth. The seedlings were fertilized with triple 20 (20-20-20) soluble $\mathrm{N}-\mathrm{P}_{2} \mathrm{O}_{5}-\mathrm{K}_{2} \mathrm{O}$, at a 0.8 $\mathrm{g} \mathrm{L}^{-1}$ rate, the first application 6 days after emergence (DAE), the second, third and fourth at 13, 19 and 26 DAE respectively. The seedlings were ready for transplant 35 days after sowing. 


\section{Field establishment and crop management}

The crop was established during the Spring-Summer 2019 cycle, in $25 \mathrm{~cm}$ high and $30 \mathrm{~cm}$ wide, by $25 \mathrm{~m}$ long seedbeds. The distance between plants within the planting beds was $30 \mathrm{~cm}$ in a single row, and $1.8 \mathrm{~m}$ between beds, covered with the colored plastic pads that were the tested treatments: black, white, red, blue and green. The plants were arranged under a completely randomized experimental arrangement with five treatments and three repetitions each, with five plants for repetition. Fertilization took place every third day via a drench, with global N-P-K fertilization of 55-45$35 \mathrm{~kg} / \mathrm{ha}$ respectively. Drip irrigation was daily applied, which for one hour and a flow rate of $0.5 \mathrm{~L} / \mathrm{h}$ for each dropper, with $20 \mathrm{~cm}$ distances between droppers. For the pests prevention and control (cochineal and snail) weekly applications of agricultural lime were made at the base of the stem of each plant ( $5 \mathrm{~g}$ approximately), the first three weeks. For whiteflies, ROMA ${ }^{\circledR}$ biodegradable detergent soap was sprayed at a rate of $5 \mathrm{~g} / \mathrm{L}$ each week.

\section{Determination of the normalized difference vegetation index (NDVI)}

The normalized difference vegetation index was determined with a GreenSeeker $^{\circledR}$ brand portable sensor, on fully developed mature leaves with the same orientation, randomly sampled (the third most developed leaf from the apex down), in three plants for each repetition. The sensor was placed on the adaxial side of the leaf to later record the data.

\section{Total soluble solids (TSS) determination in petioles}

For the determination of the total soluble solids in petioles, leaf petiole was used to determine the NDVI. Each petiole was removed from the plants with a scalpel, later in the laboratory, each sample was macerated in a porcelain mortar, until its sap was obtained, from which a drop was placed in an Atago ${ }^{\circledR}$ digital refractometer, their data recorded in Brix degrees.

\section{Epidermal sampling and determination of foliar micromorphology}

The photographs to count and the micro-morphological analysis were carried out at the Citogenética laboratory at the Departamento de Fitomejoramiento of the Universidad Autónoma Agraria Antonio Narro. The epidermal samples were collected 50 days after transplant. Epidermal impressions were made on fully mature leaves with the same orientation and from three useful plants. With a brush, transparent PVC glue was applied in an approximate $2 \mathrm{~cm}^{2}$ area. In the middle of the leaves and in secondary veins, the adaxial and abaxial sides. After the glue dried (approximately 2 min later), the glue layer was removed with transparent adhesive tape, which was then placed on a glass slide. Three photographs were taken at random of each epidermal impression, for a total of nine photographs per repeat and 27 for each treatment, in a Carl Zeiss microscope with an integrated camera (Pixera Winder Pro). With the 10X objective, the adaxial and abaxial stomatal density (SD) was determined by counting the existing stomata in the photographed area $\left(0.3965 \mathrm{~mm}^{-2}\right)$ following formula:

$$
D E=\frac{\text { Number of stomata }}{\text { area of the photograph }\left(0.3965 \mathrm{~mm}^{-2}\right)}
$$

to obtain the number of stomata per $1 \mathrm{~mm}^{-2}$. For the stomatal index (EI), photographs of the adaxial and abaxial areas were taken with a $40 x$ objective. With them, the stomatal index was estimated with the following equation:

$$
E l=(E D /(E D+E C D)) * 100
$$

where: $E D=$ stomatal density and $E C D=$ epidermal cell density, which were also assessed (Salisbury and Roos 2000).

The area of the photograph was $0.0240 \mathrm{~mm}^{-2}$ and then adjusted to $1 \mathrm{~mm}^{-2}$. With the photographs taken with the 40X objective, the length and width of the stomata were measured, recorded in micrometers, for which the Axion Vision Rel.4.8 software was used.

\section{Crop yield}

To calculate the crop yield, the filled fruits were harvested in a bag to contain them. To determine the yield per plant, the fruits were weighed on an OHAUS ${ }^{\circledR}$ Scout ${ }^{\circledR}$ Pro digital scale and the total of the three harvests was added. At the same time, the number of fruits per plant was counted. To calculate the average fruit weight, the total yield of each plant was divided by the total number of fruits that plant.

\section{Statistical analysis of the data}

For the statistical analysis of the foliar micromorphology, NDVI, total soluble solids and some yield components, a completely randomized statistical model was used with five treatments and three repetitions each, with 
a reliability of $95 \%$ and the Tukey's test $(P \leq 0.05)$, with the $S A S^{\circledR}$ statistical software version 9.02, where the treatments were the black, white, red, blue and green paddings.

\section{RESULTS AND DISCUSSION}

The averages of NDVI and total soluble solids are shown in Table 1. The amount of NDVI evaluated in husk tomato leaves was not significantly affected by the quantity and quality of solar radiation absorbed and reflected by the paddings. although the $0.87 \mathrm{NDVI}$ average of the white and red paddings is an increase compared to $8.7 \%$ of control. These values are high compared to $0.68 \mathrm{NDVI}$ obtained in watermelon crops (Saiz et al., 2017), and 0.14 and 0.35 found in two coriander varieties (Ortiz and Torres, 2018). The high NDVI values found in the husk tomato plants grown with the colored paddings, were probably due to the applied nutrition since this variable directly correlates with the amount of $\mathrm{N}$ in the plant and therefore with its greenness, which can also be interpreted as chlorophyll content (Padilla et al., 2014 and 2017). According to Hernández et al. (2017), chlorophyll content in plants increases when using lightcolored paddings and directly attributed it to a higher incidence of total solar radiation and photosynthetically active radiation on the plants. The results were found to correspond to that reported by Paredes et al. (2019), with much higher photosynthetically active radiation in red mesh followed by white one. In the total soluble solids in leaf petioles variable, no significant differences were found between treatments. Although the average of the red padding stands out with $2.18^{\circ} \mathrm{Brix}$, followed by the blue with $0.99^{\circ} \mathrm{Brix}$. The ${ }^{\circ} \mathrm{Brix}$ indicates the amount

\begin{tabular}{|c|c|c|}
\hline $\begin{array}{l}\text { Treatments } \\
\text { (Padded) }\end{array}$ & NDVI & $\begin{array}{l}\text { SST } \\
\left({ }^{\circ} \text { Brix) }\right.\end{array}$ \\
\hline Black (Control) & $0.80 \pm 0.12 a^{8}$ & $0.96 \pm 0.32 \mathrm{a}$ \\
\hline Red & $0.87 \pm 0.03 a$ & $2.18 \pm 0.81 \mathrm{a}$ \\
\hline White & $0.87 \pm 0.03 a$ & $0.97 \pm 0.60 \mathrm{a}$ \\
\hline Blue & $0.81 \pm 0.14 a$ & $0.99 \pm 0.21 \mathrm{a}$ \\
\hline Green & $0.86 \pm 0.04 a$ & $0.97 \pm 0.55 a$ \\
\hline Significance & ns & ns \\
\hline DFE & 8 & 8 \\
\hline CV (\%) & 10.36 & 49.09 \\
\hline
\end{tabular}

ns = not significant, $D F E=$ degrees of freedom of error, $C V=$ coefficient of variation, $\delta=$ mean followed by the same letter in the columns are statistically equal Tukey $\mathrm{P} \leq 0.05, \mathrm{TSS}=$ total soluble solids.

of soluble solids in a plant sample, generally sugars (Gutiérrez et al., 2017), since the more photosynthesis a plant performs, the more $\mathrm{C}$ it will be fixing to convert them into carbohydrates and transport them to areas of demand (von Caemmerer and Furbank, 2016).

The means test showed no significant differences between treatments in the variables of adaxial and abaxial epidermal cell density, or abaxial stomatal index (Table 2). This contrasts with that reported by Peralta et al. (2016), who had statistically significant differences in the stomatal index in grafted cucumbers but coincides with that by Camposeco et al. (2018) who found no significant differences in the density of epidermal cells of the adaxial part in grafted and ungrafted peppers. Therefore, it is inferred that colored plastic paddings have no significant effect on the previously described variables in husk tomato cultivation.

Table 2. Variance and comparison of means, of three foliar epidermal characters evaluated in husk tomato cultivated with different padded colors.

\begin{tabular}{l|c|c|c}
\multirow{2}{*}{$\begin{array}{c}\text { Treatments } \\
\text { (Padded) }\end{array}$} & Adaxial & \multicolumn{2}{|c}{ Abaxial } \\
\cline { 2 - 4 } & $\begin{array}{c}\text { ECD } \\
\text { (Cell mm }{ }^{-2} \text { ) }\end{array}$ & $\begin{array}{c}\text { SI } \\
(\%)\end{array}$ & $\begin{array}{c}\text { ECD } \\
\left(\text { Cell mm }{ }^{-2} \text { ) }\right.\end{array}$ \\
\hline Black (Control) & $512.35 \pm 19.27 \mathrm{a}^{\mathrm{g}}$ & $28.73 \pm 3.67 \mathrm{a}$ & $620.37 \pm 71.87 \mathrm{a}$ \\
\hline Red & $561.73 \pm 35.05 \mathrm{a}$ & $32.77 \pm 0.66 \mathrm{a}$ & $527.78 \pm 48.33 \mathrm{a}$ \\
\hline White & $569.44 \pm 12.24 \mathrm{a}$ & $30.12 \pm 1.32 \mathrm{a}$ & $606.48 \pm 25.77 \mathrm{a}$ \\
\hline Blue & $575.62 \pm 23.32 \mathrm{a}$ & $31.24 \pm 5.66 \mathrm{a}$ & $728.40 \pm 192.91 \mathrm{a}$ \\
\hline Green & $557.10 \pm 46.37 \mathrm{a}$ & $31.03 \pm 0.09 \mathrm{a}$ & $620.37 \pm 61.12 \mathrm{a}$ \\
\hline Significance & $\mathrm{ns}$ & $\mathrm{ns}$ & $\mathrm{ns}$ \\
\hline DFE & 8 & 8 & 8 \\
\hline CV (\%) & 5.72 & 9.85 & 15.94 \\
\hline
\end{tabular}

ns $=$ not significant, DFE $=$ degrees of freedom of error, $C V=$ coefficient of variation, $\varepsilon=$ mean followed by the same letter in the columns are statistically equal Tukey $\mathrm{P} \leq 0.05, \mathrm{SI}=$ stomatic index, $\mathrm{ECD}=$ epidermal cell density
In the comparison of the mean of adaxial and abaxial stomatal density and adaxial stomatal index, significant differences (Tukey; P $\leq 0.05$ ) were observed between treatments (Figure 1). This result coincides with Peralta et al. (2016), who report statistically significant differences in adaxial and abaxial stomatal index and density in grafted cucumbers. Similar results were documented in grafted and ungrafted watermelons (González et al., 2017) and in grafted peppers (Camposeco et al., 2018). With the above differences, it is observed how the plants grown with blue paddings are favored in 

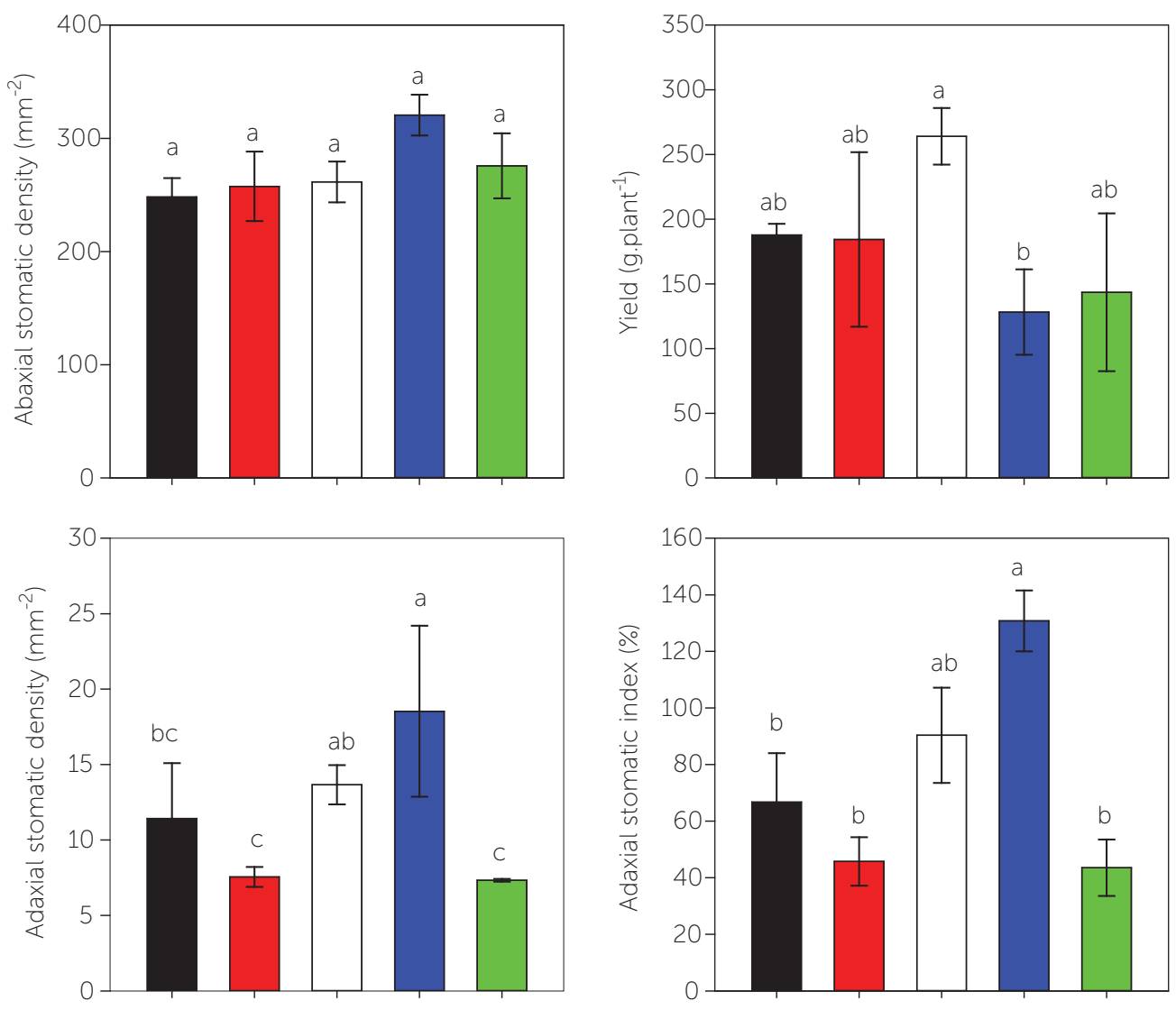

Padded color

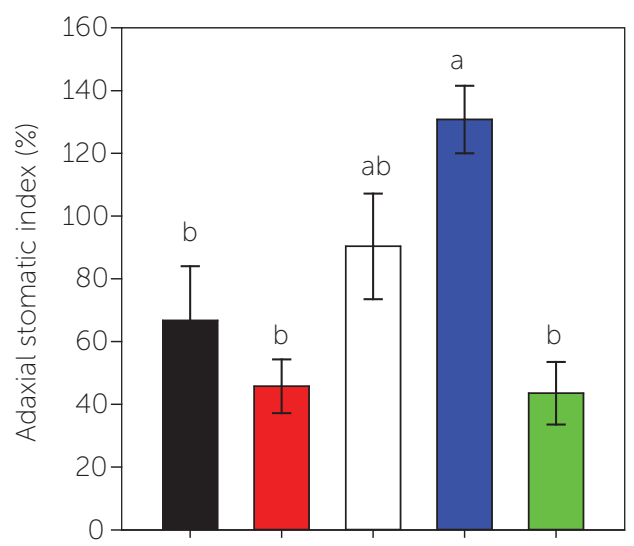

Padded color

Figure 1. Means comparison (Tukey; P $\leq 0.05$ ) of micromorphological foliar variables and yield per plant in husk tomato grown in colored plastic paddings.

the aforementioned variables. Particularly in stomatal density, which surpassed black paddings by $95 \%$ and the red and green paddings up to $150 \%$, their stomatal index reflects a similar trend. These results suggest that colored plastic padding has an effect on these variables and that the radiation absorbed and reflected by each of the colors of the plastic padding is probably different. Photosynthetically active radiation is much higher in red mesh than in blue mesh, leaving the white mesh in the middle of these, with a similar effect with respect to the average temperature (Paredes et al., 2019). Higher stomatal density directly correlates with the net $\mathrm{CO}_{2}$ assimilation rate, respiration rate, and stomatal conductance, while reducing stomatal resistance (Ayala et al., 2015). This influences the physiological efficiency of the leaves to assimilate $\mathrm{CO}_{2}$ and transform it into assimilates that are transported to the demand areas, which translates into greater productive efficiency for the plants. In addition, these conditions also favor the efficiency in the use of water and the tolerance of plants to salinity stress (Salas et al., 2001). However, the above does not fully agree with the yield, since for this variable the best yield per plant was obtained with the white padding and surpassed the blue by $85 \%$. Similar effects were reported in piquín chili when the weight of the fruits increased under white mesh and exceeded that of blue one by $7 \%$ (Paredes et al., 2019). The pearl color, red and aluminated meshes represent viable options to increase yield (Ayala et al., 2013).

The yield components evaluated are shown in Table 3. Regard the number of fruits per plant, no significant differences were found between treatments. However, the highest values were observed in the white padding, which exceeded the control by $36 \%$, while the lowest number of fruits was obtained in the green padding. The foregoing concurs with that described by Ayala et al. (2015) since peppers cultivated in white mesh produces a greater number of fruits. Paredes et al. (2019) documented a similar effect in chile piquín cultivation. These increases in fruit production are caused by favorable conditions for plant growth, caused by the plastic paddings, compared to production without paddings in open field (Li et al.,

\begin{tabular}{|c|c|c|}
\hline Treatmentes (Padded) & NFPP & AWF (g) \\
\hline Black (Control) & $5.50 \pm 2.50 a^{\mathcal{G}}$ & $39.46 \pm 18.17 a$ \\
\hline Red & $4.78 \pm 1.35 \mathrm{a}$ & $38.11 \pm 3.48 \mathrm{a}$ \\
\hline White & $7.52 \pm 0.39 a$ & $35.06 \pm 1.31 \mathrm{a}$ \\
\hline Blue & $4.54 \pm 1.28 \mathrm{a}$ & $29.23 \pm 7.99 \mathrm{a}$ \\
\hline Green & $3.56 \pm 0.41 \mathrm{a}$ & $39.48 \pm 13.66 \mathrm{a}$ \\
\hline Significance & ns & ns \\
\hline DFE & 8 & 8 \\
\hline CV (\%) & 29.59 & 30.09 \\
\hline
\end{tabular}

ns= not significant, DFE= degrees of freedom of error, $C V=$ coefficient of variation, $\delta=$ mean followed by the same letter in the columns are statistically equal Tukey $\mathrm{P} \leq 0.05, \mathrm{NFPP}=$ number of fruits per plant., AWF=average weight per fruit. 

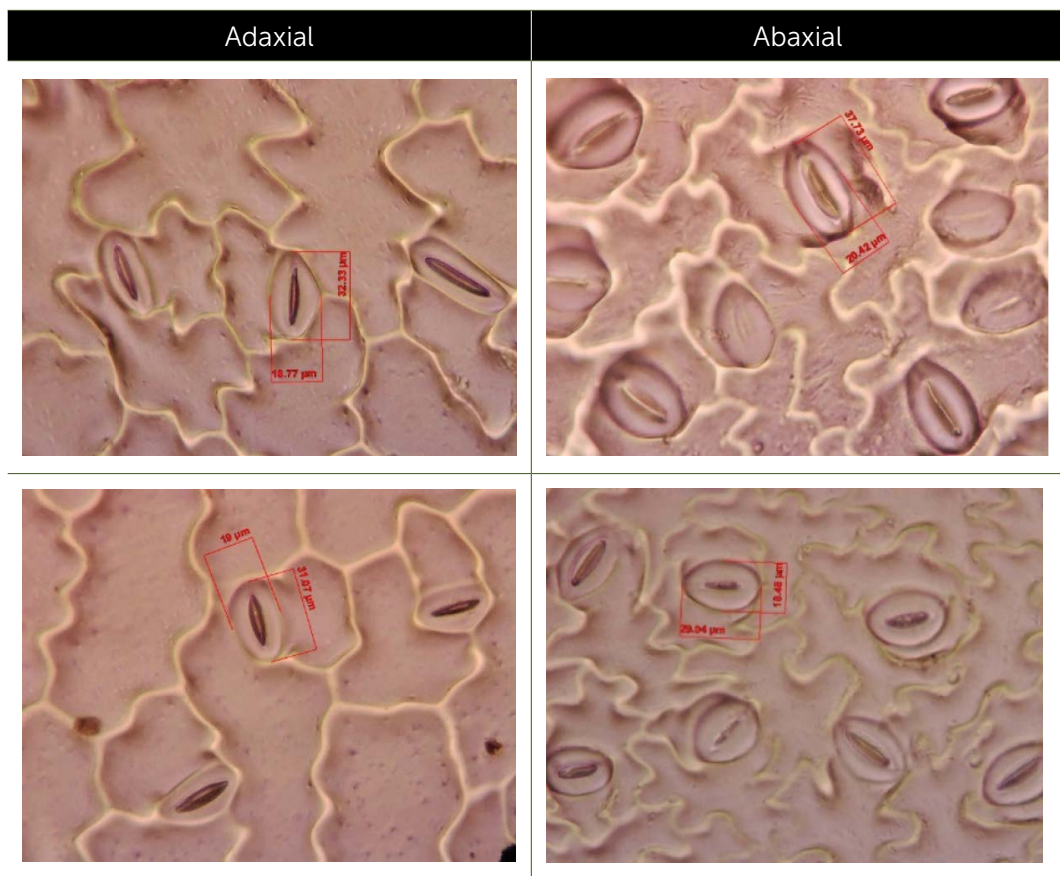

Red padded
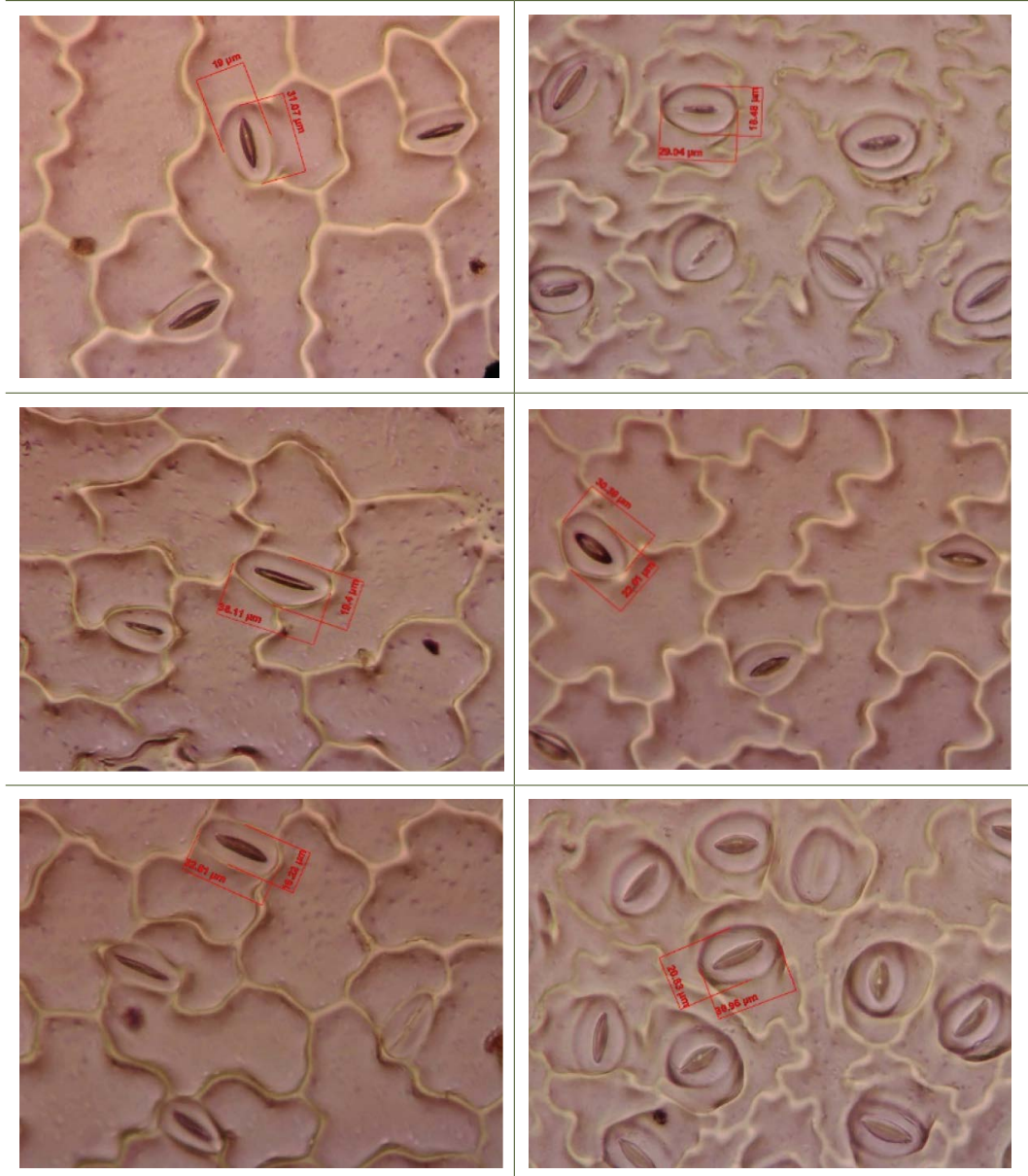

\section{White padded}

Blue padded
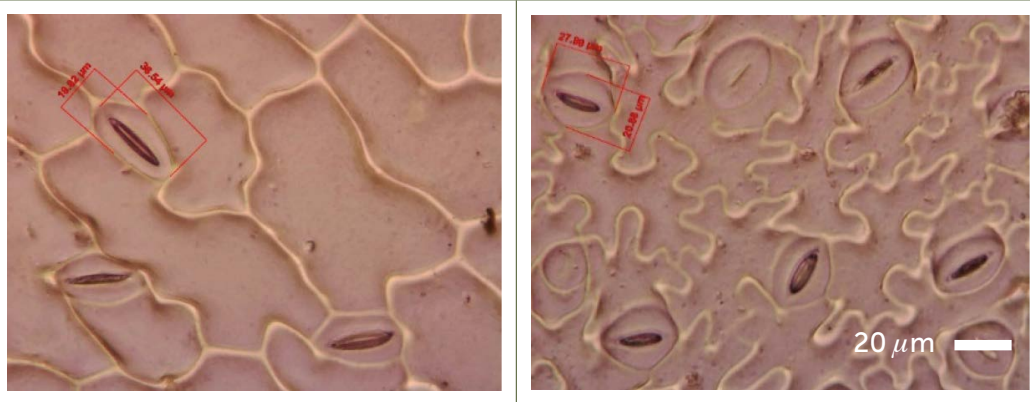

Green padded

Figure 2. Epidermis impressions of the adaxial and abaxial part of husk tomato leaves cultivated with colored paddings. 
2015). In average, fruit weights have no significant differences between treatments and the control, although the highest average values were observed in the green padding and the control, with 39.48 and $39.46 \mathrm{~g}$ respectively. Therefore, compared with Rodríguez et al. (2011), under protected agriculture conditions, husk tomato var. Querétaro obtained the highest average fruit weight with $37.65 \mathrm{~g}$, similar to that in this experiment with colored paddigs, while Valdivia et al. (2016) documented that in Physalis pubescens, up to $730 \mathrm{~g}$ per plant were obtained.

\section{CONCLUSION}

With the colored plastic paddings, some of the foliar micromorphological characteristics of the husk tomato crop are modified. The adaxial and abaxial stomatal density, as well as the adaxial stomatal index, are favored by blue plastic paddings. However, an improvement in these variables does not necessarily increase the yield of this crop.

\section{REFERENCES}

Alsadon, A., Al-Helal, I., Abdullah, I., Ahmed, A. G., Al-Zarani, S. \& Ashour. T. (2016). The effects of plastic greenhouse covering on cucumber (Cucumis sativus L.) growth. Ecological Engineering 87: 305-312

Ayala, T. F., Yáñez, J. M. G., Partida, R. L., Ruiz, E. F. H., Campos, G. F. H., Vásquez, M. O., Velázquez A. T. \& Díaz V. T. (2013). Producción de pepino en ambientes diferenciado por mallas de sombreo fotoselectivo. ITEA 111: 3-17

Ayala, T.F., Sánchez, M. R., Partida, R. L., Yáñez, J. M. G., Ruiz, E. F. H., Velázquez, A. M. T., Valenzuela, L. M. \& Parra J. (2015) Producción de pimiento morrón con mallas sombra de colores. Revista Fitotecnia Mexicana 38(1): 93-99.

Camposeco, M. N., Robledo, T. V., Ramírez, G. F., Valdez, A. L. A. Cabrera, de la F. M \& Mendoza, V. R. (2018). Efecto del portainjerto en el indice y densidad estomática de pimiento morrón Capsicum annuum var. annuum. Ecosistemas y Recursos Agropecuarios 5(15): 555-561.

Canul, T. C. E., Ibarra, J. L., Valdez, A. L. A., Lozano, del R. J., Cárdenas, F. A. \& Zermeño G. A. (2017). Influence of colored plastic mulch op soil temperature, growth, nutrimental status and yield of bell pepper under shade house conditions. Journal of Plant Nutrition 40(8):1083-1090.

Casierra, P. F., Peña, O. J. E. \& Ulrichs, C. (2011). Crecimiento y eficiencia fotoquímica del fotosistema II en plantas de fresa (Fragaria sp.) afectadas por la calidad de la luz: implicaciones agronómicas. Revista U.D.C.A Actualidad y Divulgación Científica 14(2): 43-53

Ganesh, M. N., Punyakishore, M., Jung H. P., Vaidurya, P. S, Sang Y. L. K. \& Chang H. K. (2013). UV-induced cell death in plants. International Journal of Molecular Sciences 14(1)1608-1628.

González, G. H., Ramírez, G. F., Ortega, O. H., Benavides, M. A., Robledo, T. V. \& Cabrera de la F., M. (2017). Use of chitosan-PVA hydrogels with copper nanoparticles to improve the growth of grafted watermelon. Molecules 22: 1-9.

Gutiérrez, J. A., Reyes, H. \& Castañeda, J. F. (2017). Análisis fisicoquímico de las hojas de Eucalipto camaldulensis y su hidrolizado, como sustrato en la producción de xilitol. Entre Ciencia e Ingeniería 11(22): 76-83.

Heijde, M. \& Ulm, R. (2012). UV-B photoreceptor-mediated signaling in plants. Trends in Plant Science 17(4): 230-237

Hernández, M. A., Zermeño, G. A., Melendres, A. A., Campos, M. S. G. Cadena, Z. M. \& Del Bosque V. G. A. (2017). Características de la cubierta de un túnel efecto en radiación, clorofila y rendimiento de calabacita. Revista Mexicana de Ciencias Agrícolas 8(5): 1127-1142.

Hogewoning, S. W., Trouwborst, G., Maljaars, H., Poorter, H., van leperen, W. \& Harbinson, J. (2010). Blue light dose-responses of leaf photosynthesis, morphology, and chemical composition of Cucumis sativus grown under different combinations of red and blue light. Journal of Experimental Botany. 61(11): 3107-3117.

Li, X., Shi, H., Simunek, J., Gong, X. \& Peng, Z. (2015). Modeling soil water dynamics in a drip-irrigated intercropping field under plastic mulch. Irrigation Science 33: 289-302

Oliva, M. Z. M. (2015). Efecto de colores de cubierta plástica al suelo y del manejo de poda de chile pimiento variedad Nathalie, bajo casa malla. Tesis de grado. Universidad Rafael Landivar. La Fragua, Zacapa, Guatemala

Ortiz, E. \& Torres, E. (2018). Determinación de las necesidades hídricas de dos variedades de cilantro mediante sensores remotos. Agronomía Colombiana 36: 274-283.

Padilla, F. M., Peña, F. M T., Gallardo, M. \& Thompsom, R. B. (2017) Determination of sufficiency values of canopy reflectance vegetation index for maximum growth and yield of cucumber. European Journal of Agronomy 84: 1-15.

Padilla, F. M., Peña, F. M T., Gallardo, M. \& Thompsom, R. B. (2014). Evaluation of optical sensor measurements of canopy reflectance and of leaf flavonols and chlorophyll contents to assess crop nitrogen status of muskmelon. European Journal of Agronomy 58: 39-52

Paredes, J. J. R., Mendoza, V. R., Pérez, R. M. A., Torres, V. R. \& Moreno L. S. (2019). Agronomic behavior of piquin pepper ecotypes under photoselective covers. Ingeniería Agrícola y Biosistemas 11(1): 53-67.

Peralta, M. R. M., Cabrera, de la F. M., Morelos, M. A., Benavides, M. A., Ramírez, G. F. \& Gonzales, F. J. A. (2016). Micromorfologia del pepino obtenido mediante injerto y desarrollado en dos sistemas de fertilización. Revista Mexicana de Ciencias Agrícolas 17: 3453-3463

Quintero, G. M. M. (2015). Efecto del acolchado plástico y orgánico sobre la temperatura del suelo y el rendimiento de tomate en invernadero. Tesis de Maestría. Universidad Autónoma de Nuevo León. Disponible en: http://eprints.uanl.mx/9703/

Ramos, L. B. E., Martínez, G. G. A., Morales, I., Escamirosa, C. T. \& Pérez, H. A. (2017). Consumo de agua y rendimiento de tomate de cáscara bajo diferentes cubiertas de invernadero. Horticultura Brasileira 35(2): 265-270

Rodríguez, B. A., Ayala, G. O. J., Hernández, L. A., Leal, L. V. M. \& Cortez, M. E. (2011). Desarrollo de fruto y semilla de cinco variedades de tomate de cáscara en Sinaloa. Revista Mexicana de Ciencias Agrícolas 2(5): 673-687. 
Ruiz, M. L. M., Ibarra, J. L., Valdez, A. L. A., Robledo, T. V., Benavides, M. A. \& Cabrera de la F., M. (2014). Cultivation of potato-use of plastic mulch and row covers on soil temperature, growth nutrients status and yield. Acta Agriculturae Scandinavica Section B. Soil and Plant Science 65(1): 30-35.

Saiz, R. R., Aguirre, L. G. L., Rodríguez, J. C., Watts, T. C. J., Saiz, R. J. A., Ochoa, G. A. \& Saiz, H. J. A. (2017). Estimación de evapotranspiración con imágenes de PROBA-V de un cultivo de sandía en la costa de Hermosillo, Sonora, México. Terra Latinoamericana 35: 301-308

Salas, J. A., Sanabria, M.E., \& Pire, R. (2001). Variación en el índice y densidad estomática en plantas de tomate (Lycopersicum esculentum Mill.) sometidas a tratamientos salinos. Bioagro 13(3): 99-104.

SIAP. (2019). Sistema de Información Agrícola y Pesquera. Disponible en: https://nube.siap. gob.mx/cierreagricola/

Valdivia, M. L. E., Rodríguez, Z. F. A., Sánchez, G. J. J. \& Vargas, P. O. (2016). Phenology, agronomic and nutritional potential of three wild husk tomato species (Physalis, Solanaceae) from Mexico. Scientia Horticulturae 200: 83-94.

Vargas, P. P., Valdivia M. L. E., Sánchez M. J. (2015) Potencial alimenticio de los tomates de cáscara (Physalis spp.) de México. Agroproductividad 8: 17-23.

von Caemmerer, S. \& Furbank, R. (2016). Strategies for improving C4 photosynthesis. Current Opinion in Plant Biology 31: 125-134.

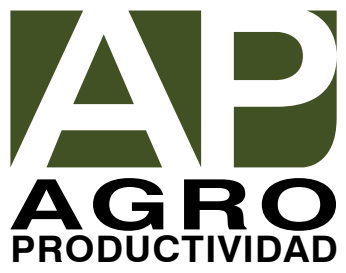

